Proc. Estonian Acad. Sci. Geol., 1997, 46, 1, 34-41

\title{
TO THE PROBLEM OF PALAEODOSIMETRICAL INFORMATION STABILITY IN ALKALI FELDSPARS
}

\author{
Galina HÜTT and Ivar JAEK
}

Geoloogia Instituut (Institute of Geology), Estonia pst. 7, EE-0001 Tallinn, Eesti (Estonia)

Presented by A. Raukas

Received 11 October 1995, accepted 24 January 1997

\begin{abstract}
The stability of holes of the centres of recombination in alkali feldspars, extracted from sediments, is studied. For the emission centres with 410 and $570 \mathrm{~nm}$ the energy of activation of thermal quenching is obtained $(>2 \mathrm{eV})$. Problems of fading and difference between thermoluminescence (TL) and optically stimulated luminescence (OSL), as well as bleachabilities, are discussed. The applicability of the orange band of emission $(570 \mathrm{~nm})$ for dating is recommended for future study.
\end{abstract}

Key words: alkali feldspars, palaeodosimetry, thermal quenching, energy of activation, spectra of stimulation.

\section{INTRODUCTION}

The stability of dosimetrical information is determined by energetical parameters of traps and centres of recombination. Stability of electrons at the traps (optical and thermal energy of activation, $E_{\text {opt }}$ and $E_{\mathrm{T}}$ ), as well as the mechanism of optically stimulated luminescence (OSL), have been studied (Hütt et al., 1988; Hütt \& Jaek, 1990). Two processes seem to be responsible for OSL: direct electron ionization from the ground state to the conduction band caused by green light stimulation $\left(E_{\text {opt }}=2.2 \mathrm{eV} ; E_{\mathrm{T}}=1.55 \mathrm{eV}\right)$ and thermooptical release of electrons caused by stimulation with infrared light from the ground to excited state $\left(E_{\text {opt }}=1.4 \mathrm{eV} ; E_{\mathrm{T}}=0.2 \mathrm{eV}\right)$ with following transition to the conduction band 
at room temperature. Temperature dependence of the OSL signal intensity reflects correlation of thermo- and optically-stimulated processes and provides evidence of the identity of the corresponding traps, essential in dating. The main problems discussed in this study are thermal stability of palaeodosimetrical information and light bleachabilities of thermoluminescence (TL) and OSL signals.

\section{EXPERIMENTAL RESULTS}

X-ray luminescence spectra of alkali feldspars, extracted from sediments, were measured. The supposed microstructure of defects and the corresponding bands of emission are presented according to Tarashchan et al. (1978) (Fig. 1). $\mathrm{X}$-ray luminescence of alkali feldspars at different temperatures and temperature quenching of luminescence emission in the maximums of two bands (410 and $570 \mathrm{~nm}$ ) were also measured (Fig. 2). Figure 2 shows that no temperature quenching is observed for the two above-mentioned emission bands at temperatures lower than $300{ }^{\circ} \mathrm{C}$. The $410 \mathrm{~nm}$ emission band is quenched a bit more rapidly. Using the equation

$$
I_{\mathrm{T}}=\frac{I_{0}}{1+p \cdot e^{-\frac{E}{k T}}},
$$

where $I_{0}$ and $I_{\mathrm{T}}$ are the X-ray luminescence intensities at room and at certain temperatures, respectively; $p$ is the factor to escape; $k$ is the Boltzmann constant; $T$ is temperature, $E$ is the energy of activation of thermal quenching:

$$
E=\frac{\ln \frac{I_{0} / I_{1}-1}{I_{0} / I_{2}-1}}{\left(k T_{2}\right)^{-1}-\left(k T_{1}\right)^{-1}}
$$

where $I_{1}, I_{2}$ are luminescence intensities at temperatures $T_{1}$ and $T_{2}$, respectively.

The energy of activation of thermal quenching for less stable centres $(410 \mathrm{~nm})$ or energy to release holes was estimated as $E_{\mathrm{T}}>2 \mathrm{eV}$. The thermal quenching value obtained does not take into consideration the quenching mechanism: in the case of external quenching the value obtained looks realistic, while for internal quenching it can be more than $2 \mathrm{eV}$.

We also measured OSL stimulation spectra for both emission bands (410 and $570 \mathrm{~nm}$ ), using the halogen lamp as a source of light. The spectra of stimulation proved identical for both bands. The infrared part of the spectrum is shown in Fig. 3. 


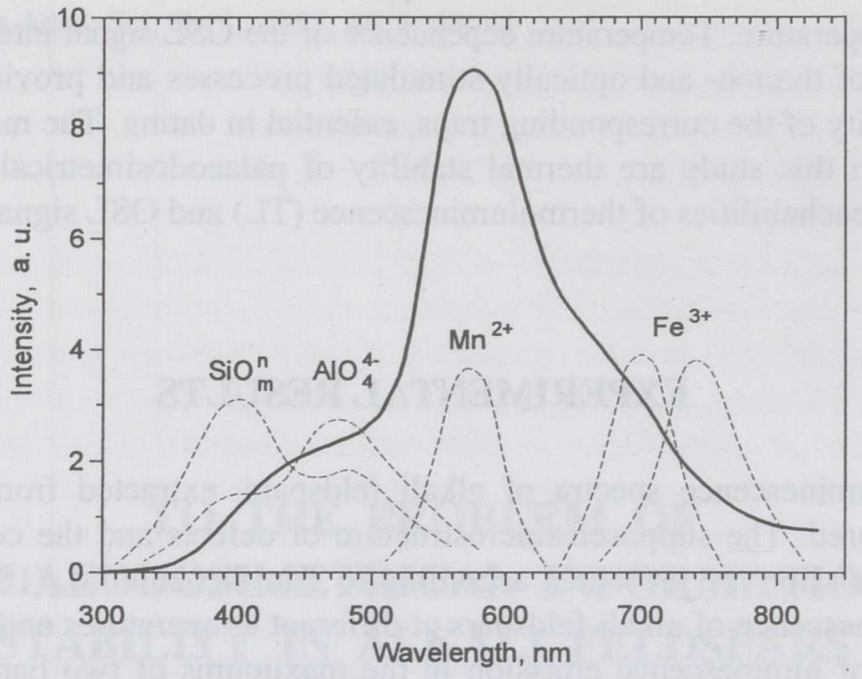

Fig. 1. X-ray luminescence of alkali feldspars at room temperature (solid line) and the supposed microstructure of defects with the corresponding emission bands (dashed lines).

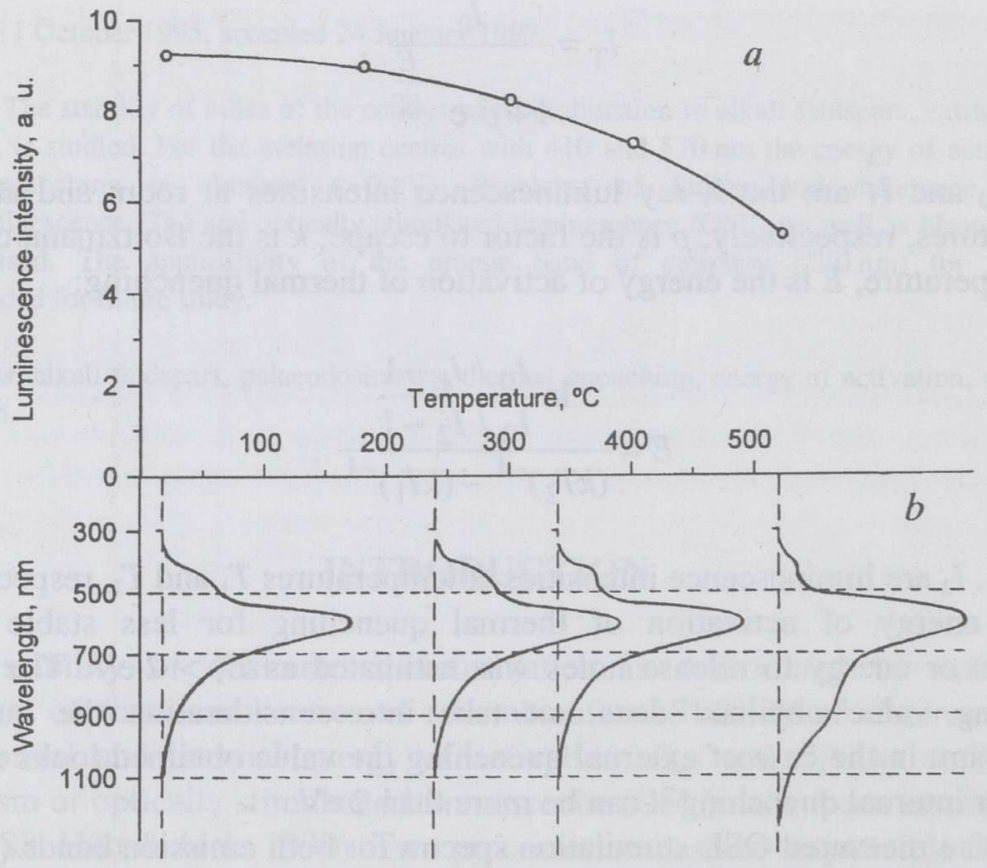

Fig. 2. Thermal quenching of emission with maximum at $410 \mathrm{~nm}(a)$ and $\mathrm{X}$-ray luminescence from room temperature to $520^{\circ} \mathrm{C}(b)$. To avoid TL influence, thermal quenching was measured at permanent X-ray excitation in the regime of cooling from $520^{\circ} \mathrm{C}$ to room temperature. 


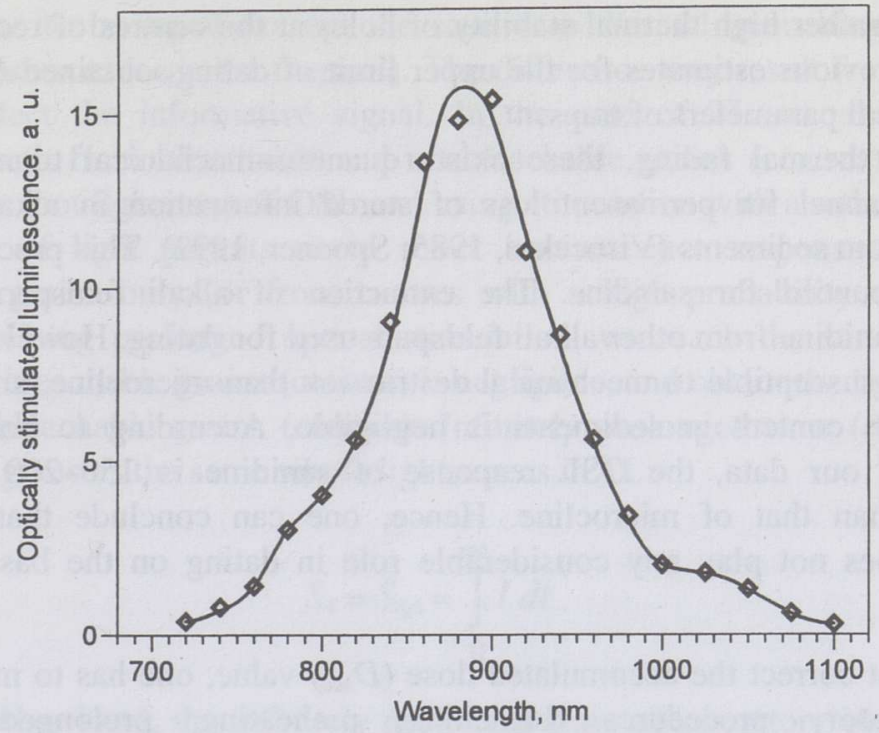

Fig. 3. Spectra of stimulation of alkali feldspars for two emission bands: 410 and $570 \mathrm{~nm}$ (infrared region) at room temperature. The source of stimulation is the halogen lamp.

As during their manufacture ancient ceramic objects were subjected to hightemperature annealing, there was a reason to analyse thermal stability of the crystal structure of alkali feldspars. According to published data (Duderov, 1957), pure K-feldspars start to decompose at $1170^{\circ} \mathrm{C}$ :

$$
\mathrm{K}_{2} \mathrm{OAl}_{2} \mathrm{O}_{3} \cdot 6 \mathrm{SiO}_{2} \rightarrow \mathrm{K}_{2} \mathrm{OAl}_{2} \mathrm{O}_{3} \cdot 4 \mathrm{SiO}_{2}+2 \mathrm{SiO}_{2} \text {. }
$$

They melt at $1510-1530^{\circ} \mathrm{C}$. However, in the temperature interval from 650 to $950^{\circ} \mathrm{C} \mathrm{K}$-feldspars undergo intensive darkening and traces of glass appear in the grains. In our experiments samples of alkali feldspars were annealed at 500, 700, and $900{ }^{\circ} \mathrm{C}$ during one hour, which corresponds to the temperature regime during the manufacture of ceramics. Before and after the annealing samples were subjected to the same doses of X-ray excitation and no changes in the intensity of OSL response were revealed.

\section{DISCUSSION}

1. The activation energy values obtained for electron and hole processes indicate high stability of stored optical information in alkali feldspars. Both centres of recombination can be used for dating purposes. It would be preferable to use the band with the maximum at $570 \mathrm{~nm}$. This ensures a 2-3 times higher intensity, which is particularly important while dating young samples. 
Thus, a rather high thermal stability of holes at the centres of recombination confirms previous estimates for the upper limit of dating, obtained on the basis of energetical parameters of traps.

Besides thermal fading, there exists quantum-mechanical tunnelling as a possible channel for permanent loss of stored information in alkali feldspars extracted from sediments (Visocekas, 1985; Spooner, 1992). This process is much more pronounced for sanidine. The extraction of alkali feldspars does not eliminate sanidine from other alkali feldspars used for dating. However, sanidine is far more susceptible to mechanical destruction than microcline, and therefore the sanidine content in sediments is negligible. According to both Spooner (1992) and our data, the OSL response of sanidine is 150-200 times less intensive than that of microcline. Hence, one can conclude that fading of sanidine does not play any considerable role in dating on the basis of alkali feldspars.

2. To get correct the accumulated dose $\left(D_{\text {acc }}\right)$ value, one has to make certain that laboratory procedures (bleaching, preheating, prolonged intensive stimulation) would not change palaeodosimeters.

The procedure for reconstructing the accumulated dose, used in Tallinn, reflects the absence of permanent fading channels or any changes of palaeodosimeters. It includes a dark pause of three weeks after irradiation and gentle stimulation with a less than $5 \%$ bleaching effect (infrared semiconductor laser, pulse duration $3 \mathrm{~s}$, wavelength $880 \pm 1 \mathrm{~nm}$, light beam power for the unit of sample surface $5 \mathrm{~mW} / \mathrm{cm}^{2}$, emission at about $400 \mathrm{~nm}$ ).

Seventeen samples from Finnish profiles (Hütt et al., 1993) were tested three weeks and one year after laboratory irradiation. The technique of full dose response curve reconstruction was used. The same accumulated doses were measured for both sets of samples. The results obtained fit with the data of Bøtter-Jensen et al. (1993).

3. Another aspect of the stability of stored information (TL or OSL) is connected with sensitivity to light of the corresponding signals (bleachability). The OSL signal is much faster bleachable and with less residual than the TL signal (Huntley et al., 1985). In the frame of the model of identity of defects, responsible for OSL and TL dating signals, attempts have been made to explain this difference. As two stages were revealed in OSL bleaching kinetics, a simple explanation could be the existence of more and less transparent mineral grains. The OSL intensity of low transparency grains is small, but the stored lightsum may be rather significant. Such grains continue to emit light even after more transparent grains have been bleached, producing a slow component. Another possible reason is that the traps, induced by the same defects, differ in the strength of oscillators (different probabilities of radiative transitions) owing to the same spectral and thermal characteristics. In general, in the case of a similar microstructure of TL and OSL defects, the optical and thermal lightsums $\left(S_{\mathrm{opt}}\right.$ 
and $S_{\mathrm{T}}$ ) have to be equal (except the case with thermal quenching, when the optical lightsum exceeds the thermal). The difference may result from the ways used to detect the informative signal. In the case of TL we always detect lightsums both from bleachable and nonbleachable grains (centres). Detecting the intensity (not lightsum) of OSL and using stimulation with a rather weak and short pulse of light permits us to select luminescence response from more transparent grains only (or from centres with a high probability of radiative transition). Using prolonged optical stimulation, we reach the state when the signal from bleachable grains (centres) is negligible, and obtain the lightsum also from hard bleachable grains (centres). Infinitely prolonged time $(t)$ of optical stimulation gives us the same whole lightsum as in TL:

$$
S_{\mathrm{T}}=S_{\mathrm{opt}}=\int_{0}^{\infty} I d t .
$$

On the other hand, the infinitely prolonged time of laboratory bleaching has to yield the same residuals both for TL and OSL techniques. However, real laboratory procedures of bleaching give a much higher residual for TL just due to collecting the signal also from hard bleachable grains (centres), which were not bleached during the limited time of laboratory treatment. The proposed model of identity of defects in alkali feldspars which are responsible for TL and OSL signals, used in luminescence dating, may lead to a contradiction: possibly we may expect that only one TL peak has to be bleached by infrared or green light, and not all of them as it happens in reality. The following explanation can be proposed. Infrared light releases electrons from the traps essential in dating, thus leading to recombination with all hole centres and their depopulation. This, in turn, leads to decreasing of all TL maxima in a wide temperature range, because they have the same spectral composition.

\section{CONCLUSIONS}

1. Values of thermal activation energy ( $>2 \mathrm{eV}$ ) obtained for two different emission bands $(410$ and $570 \mathrm{~nm}$ ) in alkali feldspars prove the upper limit of dating ( $c 10^{5}$ years). The absence of a permanent channel of fading is supported by experimental data.

2. It is recommended to study the suitability of the orange band of emission $(570 \mathrm{~nm})$ of alkali feldspars for dating.

3. Differences in bleachability, as well as in residuals of TL and OSL response dating signals, are explained within the frame of the proposed model of identity of defects responsible for those signals. It is supposed that better bleachability of the OSL signal is connected with optical selection of more transparent grains (or more easily bleachable centres). 


\title{
ACKNOWLEDGEMENTS
}

The investigation was financially supported by the Institute of Geology, Estonian Science Foundation grant 325, and International Science Foundation grant LG7000. The authors are also indebted to A. Brazulene for her assistance in measurements.

\section{REFERENCES}

Bøtter-Jensen, L., Jungner, H. \& Mejdahl, V. 1993. Recent developments of OSL techniques for dating quartz and feldspars. Rad. Prot. Dosim., 47, 1-4, 643-648.

Duderov, G. I. 1957. Otzhig keramicheskikh mass. Promstroyizdat, Moskva (in Russian).

Huntley, D. Y., Godfrey-Smith, D. I. \& Thewalt, M. L.W. 1985. Optical dating of sediments. Nature, 313, 105-107.

Hütt, G. \& Jaek, I. 1990. Photoluminescence dating of the alkali feldspars: Physical background, equipment and some results. Rad. Prot. Dosim., 34, 1/4, 73-74.

Hütt, G., Jaek, I. \& Chonka, J. 1988. Optical dating: K-feldspars optical response stimulation spectra. Quat. Sci. Rev., 7, 3/4, 381-385.

Hütt, G., Jungner, H., Kujansuu, K. \& Saarnisto, M. 1993. OSL and TL dating of buried podsols and overlying sands in Ostrobotnia, Western Finland. J. Quat. Sci., 8, 125-132.

Spooner, N. A. 1992. Optical dating: Preliminary results on the anomalous fading of luminescence from feldspars. Quat. Sci. Rev., 11, 139-145.

Tarashchan, A. N., Maksimchuk, V. G. \& Kuznetsov, G. V. 1978. Influence of impurities in X-ray luminescence of feldspars. In Using of Study of Minerals Luminescence in Geology. Proceedings of the Conference. Tallinn, Estonia, 63-66.

Visocekas, R. 1985. Tunneling radiative recombination in labradorite: Its association with anomalous fading of thermoluminescence. Nucl. Tracks Radiat. Meas., 10, 521-559.

\section{LEELISPÄEVAKIVIDE PALEODOSIMEETRILISE INFORMATSIOONI STABIILSUSE PROBLEEMIST}

\author{
Galina HÜTT ja Ivar JAEK
}

On uuritud aukude stabiilsust setetest ekstraheeritud päevakivi rekombinatsioonitsentritel. Termilise kustutamise aktivatsioonienergia on luminestsentsitsentritel kiirgusribade maksimumidega 410 ja $570 \mathrm{~nm}$ suurem kui $2 \mathrm{eV}$. On analüüsitud feedingu probleemi, samuti termo- ja fotostimulatsioonil realiseeruva valgussumma erineva väljakiiritatavuse võimalikke põhjusi. Soovitatakse edasiselt uurida oranži kiirgusriba kasutatavust setete dateerimiseks. 


\section{ПРОБЛЕМЫ СТАБИЛЬНОСТИ ПАЛЕОДОЗИМЕТРИЧЕСКОЙ ИНФОРМАЦИИ В ЩЕЛОЧНЫХ ПОЛЕВЫХ ШПАТАХ}

Галина ХЮТТ и Ивар ЯЭК

Исследована стабильность дырок на центрах рекомбинации щелочных полевых шпатов, экстрагированных из отложений. Определена энергия термической активации тушения люминесценции с максимумом излучения 410 и 570 нм (>2 эВ). Обсуждаются проблемы фединга и различия высвечиваемости термо- и оптически-стимулируемой люминесценции. Рекомендуется исследовать возможности использования оранжевой полосы излучения для датирования событий четвертичного периода. 